\title{
Research on Characteristics of Self-consciousness of Junior Middle School Students with Learning Disabilities
}

\author{
Xiaozhen Liu \\ Gannan Medical University \\ Ganzhou, China 341000
}

\author{
Yihui Li \\ Gannan Medical University \\ Ganzhou, China 341000
}

\begin{abstract}
Purpose: Research the characteristics of selfconsciousness of junior middle school students with learning disabilities and propose corresponding intervention strategies. Methods: Screen subjects through Pupil Rating Scale Revised Screening for Learning Disabilities (PRS) and carry out questionnaire for $\mathbf{3 2 0}$ junior middle school students through Piers-Harris Children's Self-concept Scale (PHCSS). Results: (1) The self-consciousness level of students with learning disabilities is obviously lower than that of excellent students. (2) The general self-consciousness levels of female and male students with learning disabilities are no obvious difference. But they are obviously different in behaviors, anxiety, happiness and satisfaction. Male students have more behavior problems than female students but the latter has stronger emotional reaction than male students. Besides, female students have poorer sense of happiness and satisfaction. (3) No obvious differences exist in self-consciousness of junior middle schools students with learning disabilities at different grades. Conclusion: The self-consciousness of students with learning disabilities is seriously damaged. Therefore, we should propose methods for them to improve self-consciousness and school records.
\end{abstract}

Keywords-junior middle school students; characteristics of self-consciousness; intervention strategies

\section{INTRODUCTION}

With the worldwide popularization of compulsory education, people pay increasingly high attention to how to provide equal opportunities for children to receive education and do more researches on students with learning disabilities. Just as Buckets Effect says, the water that a bucket can hold depends on the shortest plank instead of the longest one. Similarly, the teaching quality of a school depends on the school records of students with learning disabilities instead of that of the excellent students. Therefore, teachers shall pay special attention to students with learning disabilities.

Students with learning disabilities have normal intelligence but difficulties in understanding and using oral and written language. Teachers find those students don't have inborn defects but have difficulties in learning, fail to keep up with other students, lack interests in learning and have poor school records. They are vulnerable groups. What characteristics do they have? How do the learning disabilities influence their self-consciousness? How to help them improve school records? Parents and teachers and the society must face and solve these problems.

Extensive researches on pupils with learning disabilities began at the end of the 1980s, involving neuropsychological characteristics, behavior problems, electrical activity of brain and family factors [1, 2]. Children's self-consciousness burgeons from infancy stage and becomes mature until puberty [3]. Self-consciousness is understanding and evaluation of oneself, including mental disposition, individual mental characteristics and psychological process. The self-consciousness of human makes us adjust our thoughts and behaviors to form complete personality. Youth namely junior middle school stage is the second leaping period in the development of self-consciousness. Because of the acceleration of physiological development and the maturity of sexual development, they feel uncomfortable and unbalanced and have contradictions and confusions. Children experience strong sense of crisis. Researches at home and abroad show school records could be important factors to influence students' self-consciousness [4]. In order to research the differences between students with learning disabilities and excellent students in junior middle school and the characteristics of self-consciousness of students with learning disabilities, I research and compare 160 pairs of students with learning disabilities and excellent students in junior middle school and provide corresponding intervention strategies to improve self-consciousness of students with learning disabilities.

\section{RESEARCH OBJECTS AND METHODS}

\section{A. Research Objects}

The numbers of students with learning disabilities and excellent students selected are 160 respectively. They come from sixteen classes of grade one and grade two in a junior middle school. No invalid questionnaires exist with $100 \%$ recovery rate. Sex, grade and age of subjects are shown in "Table I". The definition standard of learning disabilities includes: the average points of major courses (Chinese, arithmetic) are within the twentieth percentile; teacher in charge of class assesses it as poor student according to learning ability and the record of at least one major course is 
lower than 60; intelligence quotient is greater than 70 points [5]. The definition standard of group of excellent students includes: the average points of major courses are within the twentieth percentile; the comprehensive assessment of student by teacher in charge of class assesses is "good". Two groups of students have no obvious physical and mental illness.

TABLE I. LIST OF INFORMATION OF SUBJECTS

\begin{tabular}{|c|c|c|c|}
\hline Sex & Grade & $\begin{array}{c}\text { Group of students } \\
\text { with learning } \\
\text { disabilities and } \\
\text { group of excellent } \\
\text { students }\end{array}$ & Age \\
\hline $\begin{array}{l}\text { Male: } 167 \\
\text { Female: } 153\end{array}$ & $\begin{array}{l}\text { Grade } 7: 160 \\
\text { Grade } 8: 160\end{array}$ & $\begin{array}{l}\text { Students with } \\
\text { learning } \\
\text { disabilities: } 160 \\
\text { Excellent students : } \\
160\end{array}$ & $\begin{array}{cr}\text { Grade } & 7 \\
13.58 \pm 0.671 \\
\text { Grade } 8 \\
14.63 \pm 0.644\end{array}$ \\
\hline
\end{tabular}

B. Research Tools

1. PRS: The scale is first compiled by American Myklebust and formed by speech and non-speech types, five composition regions and twenty-four questions [6]. Jing Jin and Zhou Ping revise it with Chinese characteristics according to English edition and Japanese revised edition [7, 8]. Students are assessed in five-level marking system. The screening standard is that the speech point is below 20 points and the non-speech point is below 40 points.

2. PHCSS: It is compiled by American psychologists Piers and Harris in 1969 and revised in 1974 to assess the self-consciousness of pupil. PHCSS contains eighty choice questions with answers of yes or no and six subscales: behavior, intelligence and school, physical appearance and property, anxiety, affiliation, happiness and satisfaction. The total point is calculated. Unified instruction is adopted and children fill in the questionnaire individually or in groups. Experimenters score with scoring key. The scale is positive scoring. The higher the point, the better the assessment of the subscale will be, namely no problems like this exist. For example, the high point in "behavior" shows this child has proper behavior; the high point in "anxiety" shows this child is in good mood without anxiety. The high total points show the child has high self-consciousness level. It is applicable for children between eight and sixteen years old.

\section{All data are managed and analyzed through SPSS18.0.}

\section{RESEARCH RESULTS AND ANALYSIS}

A. Compare Self-Consciousness Levels of Groups of Students with Learning Disabilities and Excellent Students

The result shows: The difference in total points of the two groups on PHCSS is obvious through $t$ test $(t=-5.173$, $\mathrm{P}=0<0.01)$. According to "Table II", the total points of the group of students with learning disabilities are lower than that of group of excellent students. Except for the subscale of anxiety, other subscales like behavior, intelligence and school and affiliation show the two groups of students are obviously different. The points obtained by students with learning disabilities in subscales are greatly lower than that of excellent students.

TABLE II. COMPARISON OF SELF-CONSCIOUSNESS OF TwO GROUPS OF STUDENTS $(\mathrm{M} \pm \mathrm{S})$

\begin{tabular}{|c|c|c|c|c|}
\hline & $\begin{array}{l}\text { Students } \\
\text { with } \\
\text { learning } \\
\text { disabilities } \\
(n=160)\end{array}$ & $\begin{array}{l}\text { Excellent } \\
(n=160)\end{array}$ & $\mathbf{t}$ & $\mathbf{P}$ \\
\hline Behavior & $11.46 \pm 2.647$ & $12.44 \pm 2.281$ & -3.730 & 0.000 \\
\hline $\begin{array}{l}\text { Intelligence and } \\
\text { school }\end{array}$ & $7.61 \pm 3.225$ & $10.7 \pm 3.377$ & -7.953 & 0.000 \\
\hline $\begin{array}{l}\text { Physical } \\
\text { appearance and } \\
\text { property }\end{array}$ & $5.68 \pm 3.006$ & $6.78 \pm 2.814$ & -3.373 & 0.001 \\
\hline Anxiety & $8.94 \pm 2.785$ & $9.23 \pm 2.851$ & -0.950 & 0.344 \\
\hline Affiliation & $8.51 \pm 1.965$ & $8.93 \pm 1.727$ & -2.054 & 0.042 \\
\hline $\begin{array}{l}\text { Happiness and } \\
\text { satisfaction }\end{array}$ & $7.24 \pm 1.743$ & $7.7 \pm 1.537$ & -2.712 & 0.007 \\
\hline Total points & $50.5 \pm 10.06$ & $56.11 \pm 10.09$ & -5.173 & 0.000 \\
\hline
\end{tabular}

B. Compare Self-Consciousness Level of Female and Male Students with Learning Disabilities

The result shows: The different in total points of female and male students in learning disabilities on PHCSS is not obvious through $\mathrm{t}$ test $(\mathrm{t}=1.162 \mathrm{P}=0.247>0.05)$. But according to "Table III", female and male students have obvious difference in subscales like behavior, anxiety, happiness and satisfaction. Male students with learning disabilities get lower points than the female in the subscale of behavior; female students with learning disabilities get lower points than the male in the subscales of anxiety, happiness and satisfaction.

TABLE III. COMPARISON OF SELF-CONSCIOUSNESS OF FEMALE AND Male STUdenTS WITH LEARNING DisAbilities $(\mathrm{M} \pm \mathrm{S})$

\begin{tabular}{lcccc}
\hline & $\begin{array}{c}\text { Male } \\
(\mathbf{n = 9 5})\end{array}$ & $\begin{array}{c}\text { Female } \\
(\mathbf{n = 6 5})\end{array}$ & $\mathbf{t}$ & $\mathbf{P}$ \\
\hline $\begin{array}{l}\text { Behavior } \\
\text { Intelligence and } \\
\text { school }\end{array}$ & $11.03 \pm 2.838$ & $12.08 \pm 2.217$ & -2.494 & 0.014 \\
$\begin{array}{l}\text { Physical } \\
\text { appearance and } \\
\text { property }\end{array}$ & $7.69 \pm 3.025$ & $7.48 \pm 3.518$ & 0.418 & 0.676 \\
$\begin{array}{l}\text { Anxiety } \\
\text { Affiliation }\end{array}$ & $9.04 \pm 3.010$ & $5.15 \pm 2.943$ & 1.858 & 0.065 \\
$\begin{array}{l}\text { Happiness } \\
\text { satisfaction }\end{array}$ & $8.55 \pm 1.832$ & $8.45 \pm 2.158$ & 0.319 & 0.750 \\
Total points & $7.52 \pm 1.656$ & $6.83 \pm 1.799$ & 2.481 & 0.014 \\
\hline
\end{tabular}

C. Compare Self-Consciousness Assessment of Students with Learning Disabilities in Different Grades

The result shows: According to "Table IV", except for obvious differences in age, the total points or points in subscales of students with learning disabilities at grade 7 and grade 8 are not obviously different. The result provides convenience for educators to formulate and implement intervention strategies for students with learning disabilities. 
TABLE IV. COMPARISON OF SELF-CONSCIOUSNESS OF STUDENTS WITH LEARNING DISABILITIES IN DIFFERENT GRADES $(\mathrm{M} \pm \mathrm{S})$

\begin{tabular}{|c|c|c|c|c|}
\hline & Grade 7 & Grade 8 & $\mathbf{t}$ & $\mathbf{P}$ \\
\hline Age & $13.58 \pm 0.671$ & $14.63 \pm 0.644$ & -10.1 & 0.000 \\
\hline Behavior & $11.51 \pm 2.61$ & $11.4 \pm 2.698$ & 0.268 & 0.789 \\
\hline $\begin{array}{l}\text { Intelligence and } \\
\text { school }\end{array}$ & $8.05 \pm 3.486$ & $7.16 \pm 2.897$ & 1.751 & 0.082 \\
\hline $\begin{array}{l}\text { Physical } \\
\text { appearance and } \\
\text { property }\end{array}$ & $6.09 \pm 2.99$ & $5.28 \pm 2.985$ & 1.72 & 0.087 \\
\hline Anxiety & $9.06 \pm 2.552$ & $8.81 \pm 3.011$ & 0.566 & 0.572 \\
\hline Affiliation & $8.7 \pm 1.789$ & $8.31 \pm 2.12$ & 1.249 & 0.213 \\
\hline $\begin{array}{l}\text { Happiness and } \\
\text { satisfaction }\end{array}$ & $7.38 \pm 1.679$ & $7.1 \pm 1.804$ & 0.998 & 0.320 \\
\hline Total points & $51.64 \pm 9.93$ & $49.39 \pm 10.11$ & 1.404 & 0.162 \\
\hline
\end{tabular}

\section{DISCUSSION}

\section{A. Self-Consciousness of Students with Learning Difficulties Is Seriously Damaged.}

Self-consciousness is understanding and evaluation of oneself and important for individuals to achieve socialization goals and improve personality characteristics. Researches find: Learning disabilities have close relationship with students' self-consciousness [9]. The research shows the total point of group of students with learning disabilities in the scale of self-consciousness is lower than that of excellent students. Except for the subscale of anxiety, other subscales like behavior, intelligence and school, and affiliation of the two groups are obviously different. Furthermore, the points of students with learning disabilities in subscales are obviously lower than that of excellent students. It shows the self-consciousness of students with learning disabilities is seriously damaged. They have low self-assessment, poor sense of happiness and satisfaction. Compared with excellent students, they have more problems in behaviors and emotions. It complies with the research results of Zhao Min [10]. The reason why no obvious differences exist in anxiety subscale of the two groups of students is that both of them are in youth. Because great changes happen in this period, they feel uncomfortable, unbalanced and have contradictions and confusions so they have strong sense of crisis. School records are important for students to get social recognition, self-esteem and develop positive and healthy selfconsciousness. They value school records. Although excellent students get praise and affirmation from family, school and society, these assessments will bring them intangible pressure so they fear to disappoint others if they fail to get high school records; students with learning disabilities fear parents and teachers will criticize and deny them and peers will laugh at and exclude them if they fail in the examination. Therefore, the two groups have no obvious difference in subscale of anxiety. It is lower than the norm level $(9.35 \pm 2.85)$.

\section{B. Differences in Characteristics of Self-Consciousness of Female and Male Students with Learning Disabilities}

According to Table 3, the total points of female and male students in PHCSS have no obvious differences, but female and male students are obviously different in subscales of behavior, anxiety, happiness and satisfaction. Male students with learning disabilities get lower points in subscale of behavior than the female. It shows male students have more behavior problems than female students; but female students get lower points in subscales of anxiety, happiness and satisfaction. It shows female students have more obvious emotional problems and poor sense of happiness and satisfaction. It is because female students have exquisite emotions and act impetuously in dealing with problems. They have the tendency of self-depreciation and desperateness. It complies with the research results of $\mathrm{Su}$ Linyan [11].

According to the research results that the selfconsciousness of students with learning disabilities has serious problems, the following measures are proposed:

1) Individual intervention: Improve the level of selfrecognition through individual counseling, learn to choose proper reference system and self-motivation strategies. Appropriate goals contribute to our success, improvement of self-assessment and increase self-confidence in continuous motivation.

2) School intervention: According to investigation and research of Ye Jin [12], the reason of students' learning disabilities is that teachers are derelict of duty and make mistakes at work. Some teachers attribute the poor performance of students with learning disabilities to their idleness and force them to do exercises repeatedly. As a result, it does not help students with learning disabilities to improve performance but lead to the strong study-weariness of them. Therefore, teachers should help students with learning disabilities to find reasons, effectively take corresponding intervention measures, and help them conclude successful experience in learning and apply it to other difficult learning activities and reasonably carry out classified education and support.

3) Family intervention: Investigation reveals that: Poor performance of students in school is because they lack favorable growth environment in childhood in most cases [12]. Some parents don't have good artistic appreciation or have family conflicts. Instead of giving timely guidance, they severely punish children with learning disabilities. Therefore, parents should properly improve self-cultivation, grasp scientific methods of family education, communicate with children, encourage and support them and build good parenthood.

\section{CONCLUSION}

The research results reveal the self-consciousness of junior middle school students with learning disabilities is seriously damaged. They have more behavior problems and problems in social contact because others elbow them out more easily than excellent students. With less sense of happiness and satisfaction and experience of negative emotions like loneliness, fear and self-abasement, they require more attention and love from school, family and society. Comprehensive and effective strategies are used to help pupil with learning disabilities to correctly recognize themselves and improve their self-consciousness and build harmonious and healthy ego state. 


\section{REFERENCES}

[1] Cheng Duhuo, Liu Shaowen, Gong Yaoxian. Stability of Management Structure of Pupil with Learning Difficulties [J], Psychological Science, 1993, 16: 198

[2] Wang Hong, Fu Qinhuai, Su Zhangquan. Analysis on Intelligence Structure of Pupil with Learning Difficulties [J], Foreign Medical Sciences (Section of Maternal and Child Health), 2003, 14(2): 124125

[3] Wang Xiangdong, Wang Xilin, Ma Sibian. Rating Scale for Mental Health [M], Chinese Mental Health Journal, 1999, 306-310

[4] Robinson AP,Kehle TJ,Jenson WR.But what about smart girls? Adolescent self-esteem and sex perception as a function of academic achievement. Journal of Educational Psychology, 1986, 78(3):179183

[5] Su Linyan, Luo Xuerong, Zhang Jishui. Chinese Urban Model of PHCSS [J], Chinese Mental Health Journal, 2002, 16(1): 31-34

[6] Myklebust H.R:The pupil rating Scale reviscal, Grune and Strotton, 1981

[7] Zhou Ping. Research on Pupil Rating Scale Revised Screening for Learning Disabilities (PRS) [J], Journal of Zhenjiang Medical College, 1997, 7(4): 612

[8] Li Junrong, Zhou Ping. Research on Application of Pupil Rating Scale Revised Screening for Learning Disabilities [J], Chinese Journal of School Health, 1999, 20(6): 414-415

[9] Liu Zhenhuan, Li Hongyu, Li Yan. Analysis on Factors of Pupil with Learning Disabilities [J], China Journal of Health Psychology, 2002, 10(3): 240

[10] Zhao Min, Hong Xinrong. Research on Self-consciousness of Pupil with Learning Disabilities [J], Journal of Applied Clinical Pediatrics, 2002, 17(4): 412-413

[11] Su Linyan, Wan Guobin, Yang Zhiwei. Revision of Piers Harris Children's Self-concept Scale in Hunan [J], Chinese Journal of Clinical Psychology, 1994, 2(1): 14-18

[12] Ye Jin. Let Pupil with "Learning Disabilities" Break through the Dilemma [J], Journal of Educational Science of Hunan Normal University, 2006, (5): 101-104. 